\title{
Assessment of Calorific Value of Biogas after Carbon Dioxide Adsorption Process Using Natural Zeolite and Biochar
}

\author{
Ambar Pertiwiningrum, Andang W. Harto, Margaretha A. Wuri, and Rachmawan Budiarto
}

\begin{abstract}
We evaluated the adsorption of $\mathrm{CO}_{2}$ in biogas mixtures using the combination of adsorbents: natural zeolite-natural zeolite $(Z-Z)$, natural zeolite-chicken manure based biochar (Z-CM) and natural zeolite-biogas sludge based biochar (Z-BS). The amount of $\mathrm{CO}_{2}$ adsorption was controlled at room temperature and under a gas pressure range of 5-7 bar. Samples of biogas before and after adsorption were analyzed by gas chromatography (GC) to determine the percentage of $\mathrm{CH}_{4}$. The relationship between the percentage of $\mathrm{CH}_{4}$ composition and calorific value of biogas was investigated. The results of data from GC showed that the highest $\mathrm{CH}_{4}$ enrichment was performed by $\mathrm{Z}$-CM $(28.92 \%)$. The highest $\mathrm{CH}_{4}$ enrichment increased the calorific value of biogas in comparison to biogas before adsorption. The result suggested that $\mathrm{CO}_{2}$ adsorption using natural zeolite and chicken manure based biochar successfully increased the calorific value of biogas.
\end{abstract}

Index Terms-Biogas, $\mathrm{CO}_{2}$ adsorption, calorific value, and biochar.

\section{INTRODUCTION}

Developing countries are giving more emphasis on renewable energy to reduce greenhouse emission that triggers global warming and climate changes. However, fossil fuel has been the primary energy source in developing countries and the continuous use of fossil fuel will further aggravate environmental pollution posing a major threat to human health. The mitigation of carbon dioxide $\left(\mathrm{CO}_{2}\right)$ emission from fossil fuel demands the exploration of renewable energy, such as biogas, to reduce the dependency on fossil fuel based energy [1]. Biogas is a clean energy that has been popularized as substitute for fossil fuel for the purpose of energy saving and environmental protection [2]. According to Liu et al. [3] that greenhouse gases (GHGs) emission from the utilization of biogas was much less than that of fossil fuel such as coal. This statement is also supported by Cuellar and Webber [4]. Fig. 1 showed the comparison study on GHGs emission between two scenarios: (a) business as usual, coal is burned to produce electricity and

Manuscript received March 19, 2018; revised September 1, 2018. This work was supported in part by the Graduate School Grant of Gadjah Mada University.

A. Pertiwiningrum is with the Faculty of Animal Science of Universitas Gadjah Mada, Yogyakarta, CO 55281 Indonesia (e-mail: artiwi@mail.ugm.ac.id).

A. W. Harto and R. Budiarto are with the Engineering Physics Department, Universitas Gadjah Mada, Yogyakarta, CO 55281 Indonesia (e-mail: andangftn@yahoo.com, rachmawan@yahoo.com).

M. A. Wuri is with the Environmental Engineering Department, Christian University of Surakarta, Surakarta, CO 57143 Indonesia (e-mail: margarethaarnita@gmail.com). livestock manure is left in the open air and (b) the treatment of livestock manure in anaerobic digester to generate electricity which offset coal-fired power. Total emission from coal electricity and untreated livestock manure were 65.9 to 109.3 million metric tons (MMT) and 58.8 MMT to $117.9 \mathrm{CO}_{2}$ respectively. Replacing coal-fired power and manure GHGs emission with biogas generated fewer $\mathrm{CO}_{2}$ emission only of 69.9-76.8 MMT.
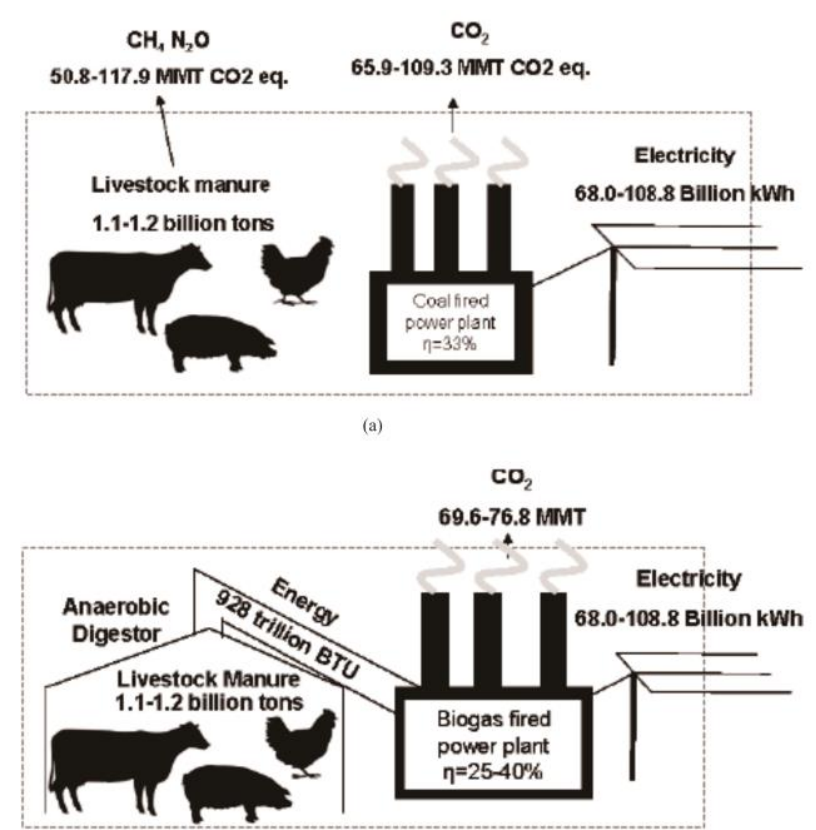

Fig. 1. Calculation of GHGs emission from coal-fired power and biogas [4]

Biogas is produced through anaerobic digestion of biomass for example from livestock waste, agriculture waste, human waste, biodegradable domestic waste, etc. Based on Ministry of Agriculture's report, the number of cattle in Indonesia is large enough, about 16 million in 2016 [5] and this number will possibly increase for next years, following the increase in human population. It will lead to the increase of livestock waste. Usually, most of cattle manure collected from outdoor are naturally decomposed. The collected manure has great potential to produced energy through anaerobic digestion. The use of manure as energy source is suitable and it becomes an efficient technology to mitigate $\mathrm{CH}_{4}$ emission that has 21 times of global warming potential than $\mathrm{CO}_{2}$ [6]. Reference [4] reported that replacing coal with manure would produce net potential GHGs emission reduction of 99 MMT or $3.9 \%$ of the annual GHGs emission from electricity in the US. Moreover, the use of manure has an important role in reducing livestock waste. Because of 
multiple benefits of biogas technology in mitigating GHGs emission and reducing livestock waste, the government encourages the use of new technology to enhance local biomass. The adoption of new technology is expected to raise human health and income level of small households.

Despite the concerted efforts made to promote the use of biogas in Indonesia, the rate of its uptake is lower compared to other developing countries such as India [7]. The efficiency of biogas energy depends on its calorific value [8]. Biogas contains $50-70 \% \mathrm{CH}_{4}$ and $30-40 \% \mathrm{CO}_{2}$ [9]. The anaerobic digestion process in biogas production is shown in Fig. 2. The presence of $\mathrm{CO}_{2}$ will reduce the calorific value and increase the compression and transportation cost [10]. In order to overcome the negative impact of $\mathrm{CO}_{2}$ in biogas, it is important to remove $\mathrm{CO}_{2}$ from biogas mixtures.

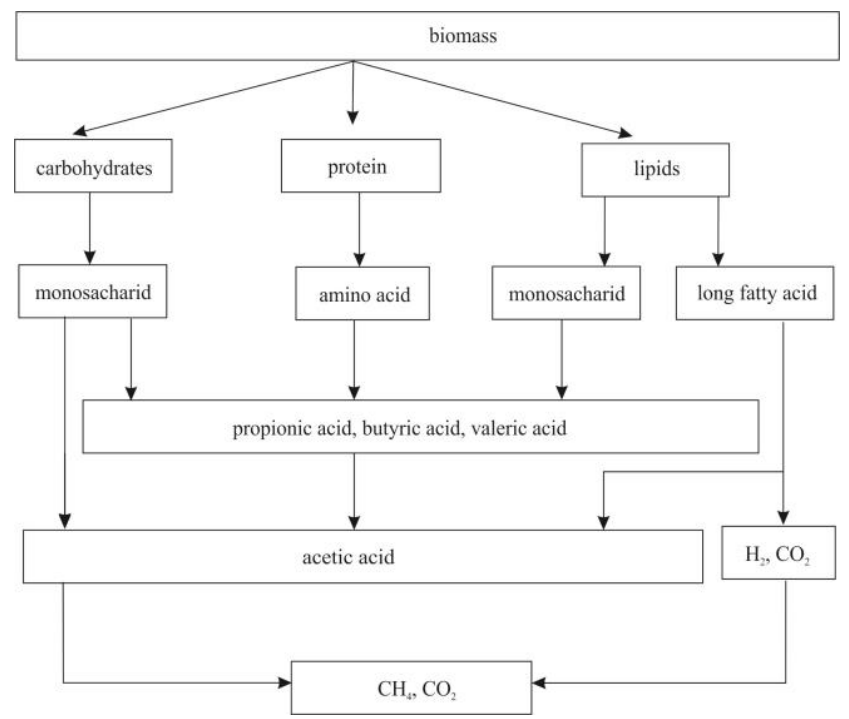

Fig. 2. Conversion pathway of biomass into biogas in anaerobic digestion [1].

A large number of technologies to remove $\mathrm{CO}_{2}$ have been developed to date such as water scrubbing, chemical scrubbing, cryogenic separation, membrane technology and adsorption [10]-[12]. Recent technologies show that adsorption is promising for $\mathrm{CO}_{2}$ removal since it is inexpensive and adoptable over the wide range of temperature and pressure condition [13]. Adsorption only requires low energy and capital cost compared to other technologies [14]. There are many researches on $\mathrm{CO}_{2}$ adsorption on porous materials such as zeolite, activated carbon and biochar [13]-[16] but studies on $\mathrm{CO}_{2}$ adsorption using chicken manure or biogas sludge based biochar in biogas mixtures are still rare. Nguyen and Lee [16] had studied pure $\mathrm{CO}_{2}$ adsorption using chicken manure based biochar of $2.18 \mathrm{mmol} / \mathrm{g}$ and $1.53 \mathrm{mmol} / \mathrm{g}$ at the temperature of $20^{\circ} \mathrm{C}$ and $30^{\circ} \mathrm{C}$ respectively. Therefore, the objectives of this study were: (1) to assess biogas characteristics upon the application of carbon dioxide adsorption process using the combination of natural zeolite and chicken manure or biogas sludge based biochar and (2) to calculate the calorific value of biogas after $\mathrm{CO}_{2}$ adsorption (purified biogas).

We selected chicken manure based biochar because it was abundant in livestock sector in Indonesia while we selected biogas sludge because it reduces biogas waste and lead to bio-cycle biogas production system. Bio-cycle through reuse, reduce and recycle will give optimal benefits for the communities and environment. In this study $\mathrm{CO}_{2}$ adsorption in biogas mixtures was undertaken at room temperature and under a gas pressure of 5-7 bar.

\section{MATERIALS AND METHODS}

\section{A. Materials}

The natural zeolite was purchased from Bratachem. Chicken manure was collected from PT Chaorend Phokpand while biogas sludge was collected from biogas production of chicken manure in Kaliurang. Biogas used in this study was supplied by the Center of Agrotechnology Innovation, Gadjah Mada University.

\section{B. Production of Biochar}

Chicken manure and biogas sludge were used as feedstock in biochar production. The dried materials were converted into biochar through pyrolysis in cylinder reactor at temperature of $500^{\circ} \mathrm{C}$ for 4 hours. Then the biochar was left cool at room temperature.

\section{Removing $\mathrm{CO}_{2}$ through Adsorption Technology}

The adsorption was carried out by two columns that were interconnected with a gas compressor through a pipe. The columns have the diameter of $40 \mathrm{~mm}$ and length of $200 \mathrm{~mm}$. To control and to measure the flow rate of the incoming and outgoing gas, we used flowmeter with pressure range of 0-25 liter per minute (LPM). The incoming gas was controlled at range of 10-15 LPM. The detail of adsorption system and formulation of adsorbents are shown in Fig. 3 and Table I respectively. The adsorption of $\mathrm{CO}_{2}$ in biogas mixtures was represented by methane enrichment, shown by the analyzed data from gas chromatography (GC).

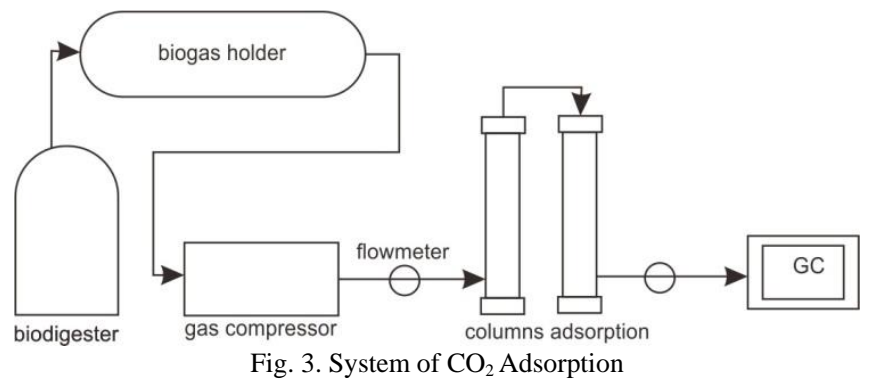

TABLE I: FORMULATION OF THE COMBINATION OF ADSORBENTS

\begin{tabular}{lll}
\hline \hline Code & Column 1 (40:40 grams) & Group 2 \\
\hline Z-Z & $\begin{array}{l}\text { Natural zeolite:natural zeolite } \\
\text { Natural zeolite:chicken manure }\end{array}$ & $\begin{array}{l}\text { Natural zeolite:natural zeolite } \\
\text { Natural zeolite:chicken } \\
\text { Z-CM }\end{array}$ \\
$\begin{array}{l}\text { based biochar } \\
\text { Natural zeolite:biogas sludge } \\
\text { based biochar }\end{array}$ & $\begin{array}{l}\text { Natural zeolite:biogas sludge } \\
\text { based biochar }\end{array}$ \\
\hline \hline
\end{tabular}

\section{Calculation of Calorific Value}

The $\mathrm{CO}_{2}$ removal from biogas mixtures helps to increase the calorific value. According to the law of conversation of energy, the input energy is the same as output energy. So the calorific value of biogas could be determined by calculating the calorific energy produced from heating water with biogas fuel. The detail of the formulation for to calculate the 
calorific energy $(Q)$ using (1):

$$
Q=\operatorname{mxc} x \Delta T
$$

$m$ represents mass of heating water $(\mathrm{kg}), c$ is specific heat of water $(\mathrm{kJ} / \mathrm{kgK})$ and $\Delta T$ is the difference between initial and final temperature of water $(\mathrm{K})$.

\section{RESULTS AND DISCUSSION}

The adsorption process aims to remove $\mathrm{CO}_{2}$ from biogas mixtures so the percentage of $\mathrm{CH}_{4}$ can be increased. The raw and purified biogas were analyzed using GC to determine the percentage of $\mathrm{CH}_{4}$. In this study, purified biogas samples were taken from biogas that had been through $\mathrm{CO}_{2}$ adsorption process with 10 minutes of contact time. Fig. 4 showed the increase of $\mathrm{CH}_{4}$ level after adsorption. This phenomenon was also found in previous studies [13]-[16]. The lowest $\mathrm{CH}_{4}$ enrichment was performed after adsorption using Z-Z. Fig. 4 and Table II showed that the combination of natural zeolite and biochar gave higher $\mathrm{CH}_{4}$ enrichment than pure adsorbents (Z-Z). The higher $\mathrm{CH}_{4}$ enrichment performed by partial subtitution of natural zeolite with biochar was due to the wider specific surface area of biochar compared to the one of natural zeolite. Biochar's surface area is made of many aromatic carbons that form pore structure [17] so it implies an increase of specific surface area. The highest $\mathrm{CH}_{4}$ enrichment was performed by natural zeolite and chicken manure based biochar (Z-CM) of $28,92 \%$ compared to raw biogas. The second highest was the biogas that had been through $\mathrm{CO}_{2}$ adsorption using the combination of natural zeolite and biogas sludge based biochar (Z-BS) of $5,12 \%$. Reference [18] reported that specific surface area of adsorbent had important role in $\mathrm{CO}_{2}$ adsorption under a gas pressure range of 5-8 bar.

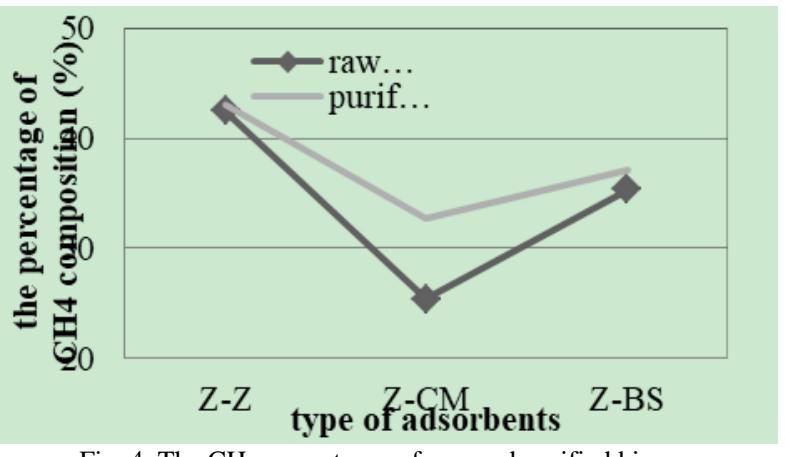

Fig. 4. The $\mathrm{CH}_{4}$ percentages of raw and purified biogas.

TABLE II: METHANE ENRICHMENT OF BIOGAS AFTER $\mathrm{CO}_{2}$ ADSORPTION

\begin{tabular}{llll}
\hline \hline Biogas & Z-Z & Z-CM & Z-BS \\
\hline Raw biogas & 42.5 & 25.35 & 35.35 \\
Purified biogas & 43.08 & 32.68 & 37.18 \\
\hline \hline
\end{tabular}

The energy of biogas can be converted to energy for cooking through combustion process. The combustible component of biogas is $\mathrm{CH}_{4}$. The raw biogas that contains $\mathrm{CH}_{4}$ has average calorific value about $30 \mathrm{MJ} / \mathrm{kg}$ but after purification, biogas can have the calorific value of $45 \mathrm{MJ} / \mathrm{kg}$ with $\mathrm{CH}_{4}$ level of $90 \%$ [19]. It means that the composition of biogas has influences on its calorific value [6]. In this study, we investigated the relationship between the percentage of $\mathrm{CH}_{4}$ and calorific value. The comparison of the calorific value of biogas is shown in Fig. 5. $\mathrm{CO}_{2}$ adsorption in biogas mixtures increased the calorific value as shown in Fig. 5. The highest increament of the calorific value was performed by the adsorption using adsorbent Z-CM of $45.06 \%$ compared to raw biogas; it was followed by Z-BS and Z-Z of $31.25 \%$ and $15.46 \%$ respectively. Besides having more pores structures, chicken manure based biochar also contains high mineral that plays important role to faciliate the capturing of $\mathrm{CO}_{2}$ molecules [20]. The energy content of biogas as shown in Fig. 5 showed that there is a correlation between the percentage of $\mathrm{CH}_{4}$ composition and calorific value. In other words, the increase of $\mathrm{CH}_{4}$ improved calorific value. We also observed that the time required to heat water using purified biogas fuel was longer compared to raw biogas.

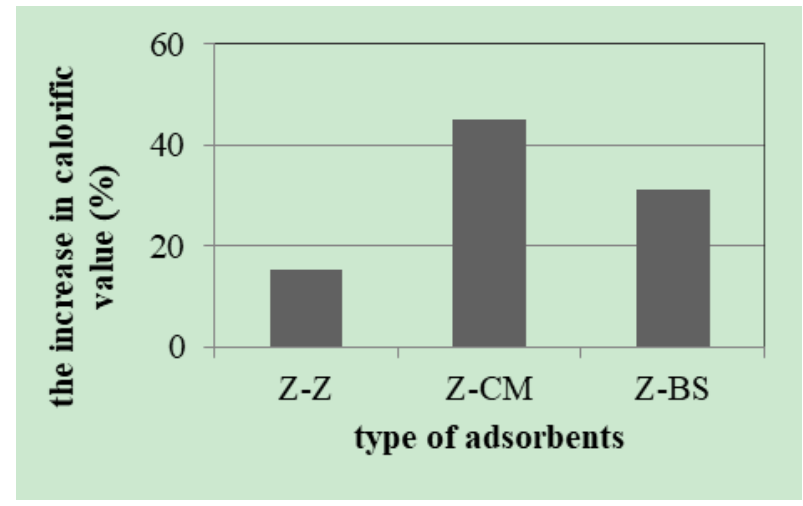

Fig. 5. The increase of calorific value in purified biogas.

\section{CONCLUSION}

The results in this study quantified the increase of calorific value in biogas mixtures after $\mathrm{CO}_{2}$ adsorption using $\mathrm{Z}-\mathrm{Z}$, $\mathrm{Z}-\mathrm{CM}$, and Z-BS. By capturing $\mathrm{CO}_{2}$, the $\mathrm{CH}_{4}$ composition in biogas increased. The highest $\mathrm{CH}_{4}$ enrichment was performed by Z-CM. From this results, we also concluded that the highest $\mathrm{CH}_{4}$ enrichment produced highest calorific energy than other samples. It means that the amount of energy used for heating water depended on the percentage of $\mathrm{CH}_{4}$ composition in biogas. This study demonstrated that $\mathrm{CO}_{2}$ adsorption using combination of natural zeolite and biochar can improve energy efficiency.

\section{ACKNOWLEDGMENT}

We would like to thank the Ministry of Research, Technology and Higher Education and the Centre of Agrotechnology Innovation, Gadjah Mada University, for its funding and support.

\section{REFERENCES}

[1] K. Hagos, J. Zong, D. Li, C. Liu, and X. Lu, “Anaerobic co-digestion process for biogas production: Progress, challenges and perspectives," Renewable and Sustainable Energy Reviews, vol. 76, pp. 1485-1496, September 2017.

[2] L. Yu, K. Yaoqiu, H. Ningsheng, W. Zhifeng, and X. Lianzhong, "Popularizing household-scale biogas digester for rural sustainable energy development and greenhouse gas mitigation," Renewable Energy, vol. 33, no. 9, pp. 2027-2035, September 2008.

[3] S. Liu, Z. Luo, and D. Zhao, "Greenhouse gas reduction and CDM analysis on countryside biogas engineering," Acta Energiae Solaris Sinica, vol. 27, no. 7, pp. 652-655, July 2006. 
[4] A. D. Cuellar and M. E. Webber, "Cow power: the energy and emissions benefits of converting manure to biogas," Environmental Research Letters, vol. 3, pp. 1-8, July 2008.

[5] Ministry of Agriculture Indonesia. (February 2017). Data lima tahun terakhir. [Online]. Available: http://www.pertanian.go.id/

[6] Intergovernmental Panel on Climate Change (IPCC), "Drivers, trends, and mitigation," Climate Change 2014: Mitigation of Climate Change Contribution of Working Group III to the Fifth Assessment Report of IPCC, Cambridge: Cambridge University Press, 2014, ch. 5, pp. $351-412$.

[7] H. Pathak, N. Jain, A. Bhatia, S. Mohanty, and N. Gupta, "Global warming mitigation potential of biogas plants in India," Environmental Monitoring and Assessment, vol. 157, pp. 407-418, October 2009.

[8] F. Lwiza, J. Mugisha, P. N. Walekhwa, J. Smith, and B. Balana, "Dis-adoption of household biogas technologies in Central Uganda," Energy for Sustainable Development, vol. 37, pp. 124-132, January 2017.

[9] A. Sun, H. Li, J. Yan, L. Liu, Z. Yu, and X. Yu, "Selection of appropriate biogas upgrading technology-a review of biogas cleaning, upgrading and utilisation," Renewable and Sustainable Energy Reviews, vol. 51, pp. 521-532, July 2015.

[10] M. R. A. Mamun, M. R. Karim, M. M. Rahman, A. M. Asiri, and S. Torii, "Methane enrichment of biogas by carbon dioxide fixation with calcium hydroxide and activated carbon," Journal of the Taiwan Institute of Chemical Engineers, vol. 58, pp. 476-481, July 2015.

[11] D. Andriani, A. Wresta, T. D. Atmaja, and A. Saepudin, "A review on optimization production and upgrading biogas through $\mathrm{CO}_{2}$ removal using various techniques," Applied Biochemical Biotechnology, vol 172, pp. 1909-1928, November 2013

[12] O. W. Awe, Y. Zhao, A. Nzihou, D. P. Minh, and N. Lyczko, "A review of biogas utilisation, purification and upgrading technologies," Waste Biomass Valor, vol. 8, pp. 267-283, January 2017.

[13] L. Hauchhum and P. Mahanta, "Carbon dioxide adsorption on zeolites and activated carbon by pressure swing adsorption in a fixed bed," International Journal of Environmental Engineering, vol. 5, pp. 349-356, August 2014.

[14] A. Alonso-Vicaro, J. R. Ochoa-Gomez, S. Gil-Rio, O. Gomez-Jimenez-Aberasturi, C. A. Ramirez-Lopez, J. Torrecilla-Soria, and A. Dominguez, "Purification and upgrading of biogas by pressure swing adsorption on synthetic and natural zeolites," Microporous and Mesoporous Materials, vol. 134, pp. 100-107, June 2010.

[15] A. E. Creamer, B. Gao, and M. Zhang, "Carbon dioxide capture using biochar produced from sugarcane bagasse and hickory wood," Chemical Engineering Journal, vol. 249, pp. 174-179, April 2014.

[16] M. Nguyen and B. Lee, "A novel removal of $\mathrm{CO}_{2}$ using nitrogen doped biochar beads as a green adsorbent," Process Safety and Environmental Protection, vol. 104, pp. 490-498, April 2016.

[17] A. Jain, R. Balasubramanian, and M. P. Srinivasan, "Hydrothermal conversion of biomass waste to activated carbon with high porosity: A review," Chemical Engineering Journal, vol. 283, pp. 789-805, August 2015.

[18] M. Kacem, M. Pellerano, and A. Delebarre, "Pressure swing adsorption for $\mathrm{CO}_{2} / \mathrm{N}_{2}$ and $\mathrm{CO}_{2} / \mathrm{CH}_{4}$ separation: comparison between activated carbons and zeolites performances," Fuel Processing Technology, vol. 138, pp. 271-283, June 2015.

[19] A. Noyola, J. M. Morgan-Sagastume, and J. E. Lopez-Hernandez, "Treatment of biogas produced in anaerobic reactors for domestic wastewater: Odor control and energy/resource recovery," Reviews in Environmental Science and Bio/Technology, vol. 5, pp. 93-114, February 2006

[20] X. Xu, Y. Kan, L. Zhao, and X. Cao, "Chemical transformation of $\mathrm{CO}_{2}$ during its capture by waste biomass derived biochars," Environmental Pollution, vol. 213, pp. 533-540, March 2016.

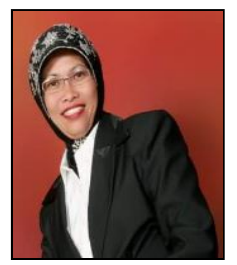

Ambar Pertiwiningrum was born in Ambarawa, on September 2, 1966. Her educational background is listed: She graduated bachelor level in Faculty of Animal Science, Universitas Gadjah Mada, Indonesia. He continued her master program in animal science in Universitas Gadjah Mada, and the last she graduated from doctoral program in Gifu University, Japan, specially in microbiological science.

In renewable energy, she was/is involved in community empowerment programs. She was/is also involved in training or workshop were: Technical Guidance Biogas in Kulon Progo Yogyakarta Special Region (2014), Technical Guidance Biogas in Palu (2014) and Utilization of Livestock Waste to Biogas and organic fertilizer delivered on Livestock Waste Management Technical Assistance Training (2014). Todays, she is a senior lecturer in Faculty of Animal Science, Universitas Gadjah Mada, Yogyakarta, Indonesia and she concerns in livestock waste management. She has published publication are: Isolation, Identification and Dehairing Activity of Indonesian Native Keratinolytic Bacteria Exiguobacterium (2015), A commentary on occupational infectious diseases due to agricultural practices in Sub-Saharan Africa (Science Direct, 2014) and so on.

Moreover doing her duties as a lecturer, Ir. Ambar Pertiwiningrum, M.Si., Ph.D. also undertakes many research focused on biogas technology and mushroom cultivation.

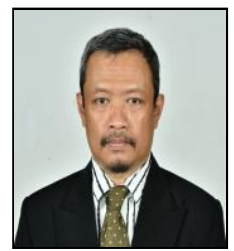

Andang W. Harto was born in Blitar, on March 4, 1966. He has graduated bachelor level at Nuclear Engineering Department, Universitas Gadjah Mada and continued to the master program at Chemical Engineering Universitas Gadjah Mada. Finally get the doctoral degree at Engineering Science Universotas gadjah Mada.

Now Mr Andang is Lecturer in Deopartment of Nuclear Engineering and Enginering Physics, Faculty of Engineering, Universitas Gadjah Mada. Andang Widi Harto has extensively done reserach in nuclear engineering, mostly in development of advanced molten salt reactor. This research has been conducted since 2006 and still in progress now. Mr Andang has published his works on Molten salt Nuclear Reactor on IJNEST Journal (2015).. In the field of renewable energy. Mr Andang conduct the research in biogas energy system, including biogas purification system, biogas packaging system, and development of small biogas turbine.

Dr. Ir. Andang Widi Harto, M.T. conduct the research in biogas energy system, including biogas purification system, biogas packaging system, and development of small biogas turbine.

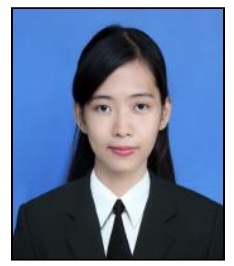

Margaretha A. Wuri was born in Surakarta, ON March 21, 1992. She graduated from the Departmen of Chemistry in Sebelas Maret University, Indonesia and continued to the master program from the Department of Technology for Sustainable Development, Environmental Science, Universitas Gadjah Mada, Indonesia

Today, she works as a lecturer in the Department of Environmental Engineering in Christian University of Surakarta, Indonesia. She also does some research related in waste treatment/ utilization and biogas purification.

Margaretha Arnita Wuri, S.Si., M.Sc. also has published research articles are: Carbon Dioxide Adsorption on Natural Zeolite and Biochar Derived Chicken Manure (Proceeding The $9^{\text {th }}$ International Graduate Students and Scholars' Conference in Indonesia, 2017) and Effect of Cyclical Tehrmal to Mechanical Properties of Hybrid Laminated Composite (HLC) with Skin Recycled Polypropylene/Natural Fiber/Halloysite and Core PP/KF (Proceeding $10^{\mathrm{th}}$ Joint Conference on Chemistry, IOP Science, 2015).

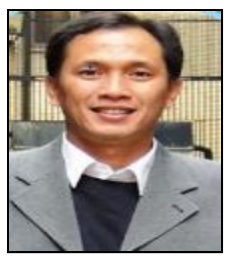

Rachmawan Budiarto was born in Yogyakarta, ON September 23, 1971. He graduated from the doctora program, reliability of renewable energy, mechanical, engineering in Faculty of Engineering, Universitas Gadjah Mada. He now is a senior lecturer in the Department of Engineering Physics, Faculty of Engineering, Universitas Gadjah Mada, Yogyakarta, Indonesia.

In renewable energy, he was/is involved in programs funded by international sources (Korindo - South Korea, GTZ/GIZ - Germany, JICA Japan, SIDA - Sweden, USAID - United States, Non Alignment Movement Centre for South-South Technical Coop (NAM CSSTC) and Shizuoka University - Japan). During 2009 - 2014 he became a team leader in 13 programs (renewable energy, green building, sensors/instrumentation and defense) which were funded by a variety of sources. In $2009-2012$ he was active in disaster mitigation activities in LPPM UGM and Indonesian National Board for Disaster Management (BNPB). He also publishes his research publications are: The Performance of Various Pozzolanic Materials in Improving Quality of Strontium Liquid Waste Cementation (Elsevier, 2013), Sustainability Challenge for Small Scale Renewable Energy Use In Yogyakarta (Elsevier, 2013), and Implementation of Islamic Economics in Indonesia by Developing Green Economy through Renewable Energy Technologies (Proceeding of Gadjah Mada, International Conference on Islamic Economics and Development, Universitas Gadjah Mada Indonesia 2016).

In 2017-2021, Dr. Rachmawan Budiarto, M.T., Ph.D. works as Director, Centre for Development of Sustainable Region, USAID- Kemenristek, Shera Grant. 